\title{
O pai do Grêmio
}

\section{The father of the guild}
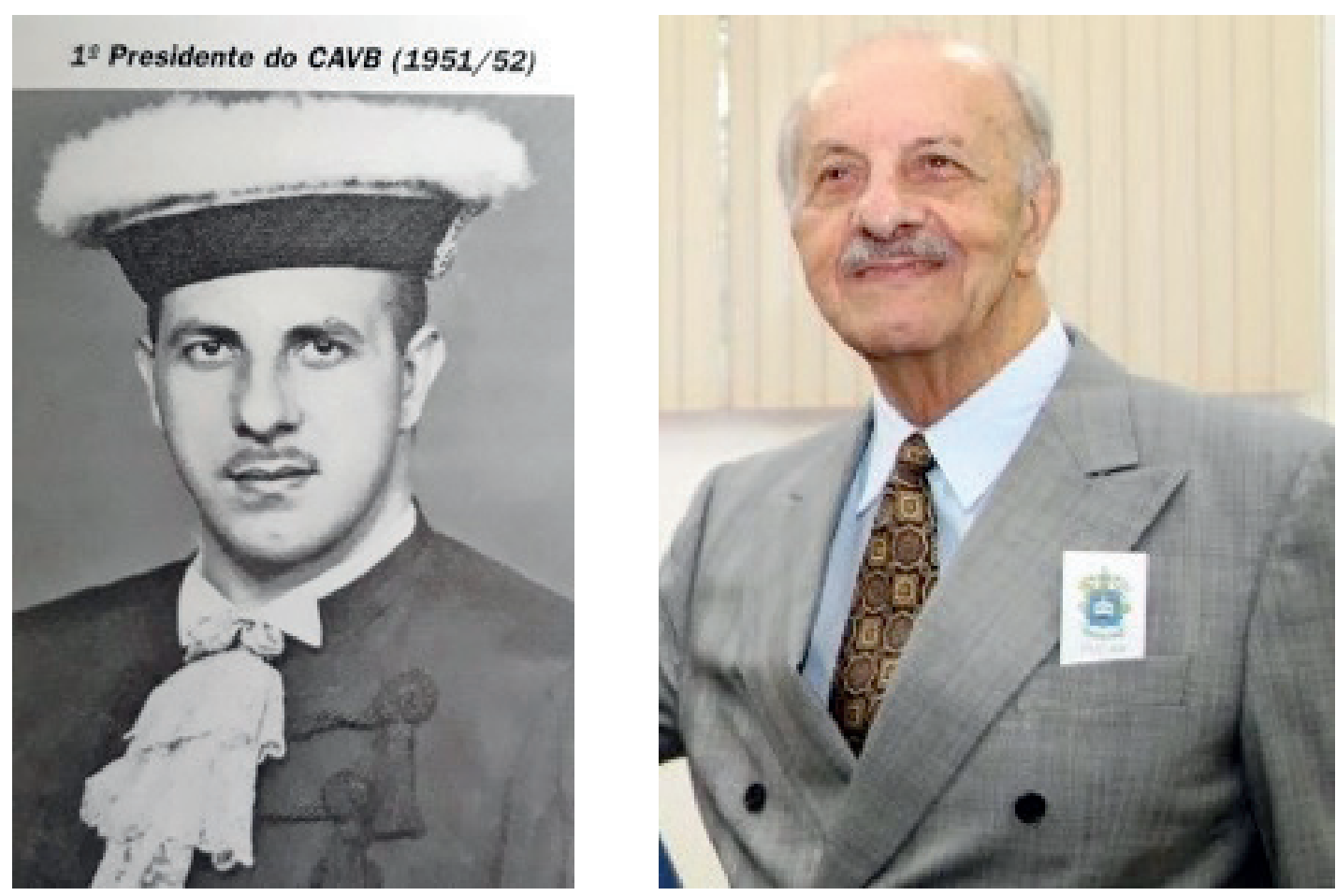

Luiz Sebastião Prigenzi

(20/01/1929-04/01/2018)

Resquiacat in pace

Sob o título "Patologia Clínica da Unicamp perde o Professor Luiz Sebastião Prigenzi", a revista daquela universidade anunciou o falecimento do fundador do Departamento de Patologia Clínica da Faculdade de Ciências Médicas da Universidade Estadual de Campinas (Unicamp). Textualmente, identificou-o como "marcado pelo seu pensamento questionador à frente de seu tempo".

Formado pela Faculdade de Medicina de Sorocaba (1956), Prigenzi atuou no campus Sorocaba da Pontifícia Universidade Católica de São Paulo (PUC-SP) como assistente de Clínica Médica (1957-1965), chefe de Clínica
(1962-1963), assistente de Química Biológica e chefe do Laboratório Central (1957-1970).

Ingressou na Unicamp em 1970 como professor do curso de pós-graduação em Imunologia e professor-assistente da disciplina de Imunologia Clínica. Doutorou-se com a tese Contribuição ao estudo da agamaglobulinemia primária adquirida (1976).

Estagiou em centros de pesquisa da Espanha, Alemanha e Inglaterra. Foi diretor geral do Instituto Adolfo Lutz (1987), presidente-executivo do Centro de Controle de Doenças da Secretaria de Estado da Saúde (1987), membro da Sociedade

'Pontifícia Universidade Católica de São Paulo, Faculdade de Ciências Médicas e da Saúde - Sorocaba (SP), Brasil.

Autor correspondente: Edgard Steffen - Rua Treze de Maio, 71, apto. 31 - Centro - CEP: 18035-150 Sorocaba (SP), Brasil E-mail: edgard.steffen@gmail.com

Recebido em 25/01/2018. Aceito para publicação em 25/01/2018. 
Brasileira de Imunologia e consultor da União Internacional das Sociedades de Imunologia Clínica.

Lembro-me perfeitamente de quando o vi pela primeira vez. No anfiteatro A, após aula inaugural ministrada pelo saudoso Prof. Dr. Odorico Machado de Souza. Retirados os professores e autoridades, Dr. João Câncio Azevedo Sampaio, secretário geral da Faculdade de Medicina de Sorocaba, sugeriu que os 51 aprovados no primeiro vestibular se apresentassem aos colegas e se preparassem para a organização de um Centro Acadêmico. O secretário chamou-nos pela classificação no vestibular. De cara, conhecemos aquele moço alto carismático que fora o primeiro colocado. Com voz forte e em palavras simples, apresentou-se. Viera de São Carlos, São Paulo. Alguns dias depois, era eleito Presidente da Comissão Organizadora do Centro Acadêmico que receberia o nome de Vital Brasil (com "s" como grafei na ata). Elaboramos o estatuto numa adaptação do vigente no Centro Acadêmico Oswaldo Cruz (CAOC) da Faculdade de Medicina da Universidade de São Paulo (FM-USP). Nas múltiplas reuniões e assembleias, Prigenzi costumava referir-se ao CAOC da Faculdade do Araxá e nós, interioranos recém-saídos do curso científico, referíamos ao nosso projeto de entidade acadêmica pelo nome Grêmio. Essa denominação o irritava sobremaneira. Não deu outra. Os humoristas de plantão passaram a identificá-lo pelo nome de guerra "Pai do Grêmio". Fundado o Centro Acadêmico Vital Brasil (CAVB), Luiz Sebastião Prigenzi foi eleito presidente, junto com José Neder (vice), Edgard Steffen (primeiro secretário), Roque Aparecida Ribeiro Lopes (segundo secretário), Tuffy Aidar Sobrinho (primeiro tesoureiro), Walter Caram Saliba (segundo tesoureiro), Paulo de Assis (orador), Diana Tannos (diretor cultural científico), Constantino José Fernandes (diretor social) e Rodolfo Magnani Filho (diretor de esportes).

Sob sua diretoria, foram criados os símbolos do CAVB, a "Festa da Amizade" (de saudosa memória) e os times de futebol, basquete e vôlei que disputaram o campeonato estudantil local e a Olimpíada da PUC-SP.

Passados 66 anos, restavam 10 daquele grupo. Cinco exerceram a profissão na própria cidade que os formou. Aposentado, Prigenzi voltou para a terra de sua esposa. A última vez que o vi, almoçava com a Nancy e as filhas Maria Laura e Maria Luisa num restaurante da cidade. Após muitos anos de gravata e avental em centros de pesquisa e/ou ensino, podia agora ser visto de bermuda e tênis, em compras para abastecimento doméstico.

Sua morte quase passou despercebida. Entre notas do obituário, o sobrenome apareceu com falta de uma consoante. Conhecendo as implicações e complicações da doença que o afligia, não aceitou quimioterapia nem intervenções cirúrgicas. Apagou para esta vida, no recesso do lar, cercado pela família que formara. Apagou sem lamentos ou temores. Como quem adormece.

Os sobreviventes da primeira turma não esquecerão aquele primeiro presidente do CAVB que faturou o primeiro lugar no primeiro vestibular da primeira Faculdade de Medicina a funcionar em cidade do interior do Brasil. Às vezes, imagino sua chegada onde estão os que partiram antes. Ao abraçá-lo, dirão em coro "Bem-vindo! Pai do Grêmio!..." só para ouvir a resposta "Não é Grêmio. É Centro Acadêmico, gente!". 